\title{
A Review on Chemical Composition, Bioactivity, and Toxicity of Myristica fragrans Houtt. Essential Oil
}

\author{
Mega Ferdina Warsito
}

Research Center for Biotechnology, Indonesian Institute of Science, Jl. Raya Bogor Km. 46, Cibinong, Bogor, Indonesia 161911.

\begin{tabular}{|c|c|}
\hline Info Article & ABSTRACT \\
\hline Submitted: 31-01-2021 & Myristica fragrans Houtt., commonly known as nutmeg, is an \\
\hline Revised: 06-06-2021 & Indonesian indigenous dioecious evergreen tree that contains $5-15 \%$ \\
\hline Accepted: 14-09-2021 & volatile oil. The oil is usually produced from the seed or mace. Nutmeg oil \\
\hline *Corresponding author & $\begin{array}{l}\text { has been extensively utilized in aromatherapy, natural medicine, and the } \\
\text { perfume industry. This article provides an overview of the chemical }\end{array}$ \\
\hline Mega Ferdina Warsito & compounds, biological potency, and toxic effects of nutmeg essential oil \\
\hline & compiled from recent literature (2000-2020). Nutmeg oil mainly comprises \\
\hline mferdina@gmail.com & monoterpenes and phenylpropanoids. Several reports on gas \\
\hline & $\begin{array}{l}\text { chromatography-mass spectrophotometry analysis of nutmeg oil showed } \\
\text { that there were } 27-38 \text { chemical constituents detected at various }\end{array}$ \\
\hline & concentrations. Many secondary metabolites of nutmeg oil are reported to \\
\hline & $\begin{array}{l}\text { show biological activities that possibly substantiate its utilization in natural } \\
\text { medicine. Numerous studies reported the biological activities of this volatile }\end{array}$ \\
\hline & antioxidant, analgesic, antiinflammation, anticonvulsant, \\
\hline & sitic, insecticidal, and anticancer activity. But large \\
\hline & $\begin{array}{l}\text { ntake of nutmeg oll could cause intoxication which is shown through } \\
\text { symptoms in the cardiovascular, central nervous system, anticholinergic, }\end{array}$ \\
\hline & and local effects in the stomach. These symptoms are mainly attributed to \\
\hline & the effect of myristicin, safrole, and elemicin overdose. This updated review \\
\hline & $\begin{array}{l}\text { developed into a medicinal product for the prophylaxis and therapy of } \\
\text { diseases. }\end{array}$ \\
\hline & eywords: Nutmeg, volatile oil, chemical composition, bioactivity, toxicity. \\
\hline
\end{tabular}

\section{INTRODUCTION}

Myristica fragrans Houtt. or nutmeg is an indigenous plant of Indonesia (Ibrahim et al., 2020; Rahardiyan et al., 2020). It has been cultivated in many tropical countries such as Malaysia, India, Indonesia, Grenada, Mauritius, Singapore, Sri Lanka, and many African countries (Al-Rawi et al., 2011; Kuete, 2017). Nutmeg is a unique kitchen spice with a distinct fragrance and warm, slightly sweet taste. It had been used traditionally as a natural remedy in Tibet, China, India, Indonesia, Arabs of Israel, and Jewish (Periasamy et al., 2016) to treat digestive problems, such as indigestion, flatulence, diarrhea, and colic, insomnia, urinary incontinence, dyspepsia, arthritis, cold, headache, pyocutaneous disease, and asynodia (Zheljazkov et al., 2015; Abourashed and El-Alfy, 2016; Periasamy et al., 2016; Zhao et al., 2017).
Nutmeg yields 5-15\% of volatile oil (Stein et al., 2001; Periasamy et al., 2016). The major constituents of nutmeg essential oil (NEO) are terpenes and alkenyl benzene derivates (Abourashed and El-Alfy, 2016). In folkloric medicine, NEO has been practically applied as a topical preparation to treat rheumatism, since it possesses analgesic and anti-inflammatory effects (Asgarpanah, 2012). In recent years, NEO has been found to have various biological properties e.g., antioxidant (Piaru et al., 2012; Adiani et al., 2015; Sipahelut et al., 2020), analgesic, antiinflammation (Zhang et al., 2016), anticonvulsant (Wahab et al., 2009), antiinfection (Gupta and Rajpurohit, 2011; Pillai et al., 2012), insecticidal (Du et al., 2014; Norris et al., 2015; Soni et al., 2016), and anticancer (Piaru et al., 2012b). 


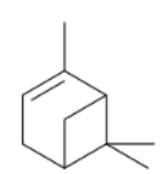

(1)

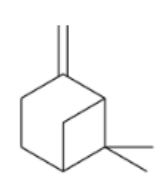

(2)

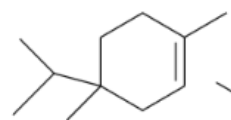

(3)<smiles>CCC1=CC=C(C)CC1</smiles>

(4)<smiles>C=C(C)C1CC=C(C)CC1</smiles>

(6)<smiles>C=C1CCC2(C(C)C)CC1C2</smiles>

(7)<smiles>C=C1C2CCC(C2)C1(C)C</smiles>

(9)

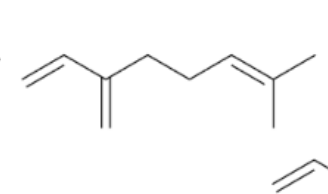

(10)<smiles>C=CCc1cc(C)c2c(c1)OCO2</smiles>

(11)<smiles>CCOc1cccc(OC)c1OC</smiles>

(12)<smiles>[R]Oc1ccc([R])cc1OC</smiles>

(13)

$\mathrm{R}_{1}=\mathrm{H} ; \mathrm{R}_{2}=\mathrm{CH}_{2} \mathrm{CHCH}_{2}$ (14)

$\mathrm{R}_{1}=\mathrm{CH}_{3} ; \mathrm{R}_{2}=\mathrm{CH}_{2} \mathrm{CHCH}_{2}$ (15)

$\mathrm{R}_{1}=\mathrm{CH}_{3} ; \mathrm{R}_{2}=\mathrm{CHCHCH}_{3}$ (16)

Figure 1. The goodness of fit of the one-compartment open model of levofloxacin after intravenous bolus injection, i.e., individual data fitting analyses (panel A); observation versus population prediction analysis (panel B) and observation versus individual prediction analysis (panel C).

Several review articles had been reported on nutmeg botanical aspect, secondary metabolites, the analytical methods used to analyze the extracts and pure compounds, phytochemical aspect, the total synthesis process of some major constituents, and the pharmacological activities of nutmeg extract (Asgarpanah, 2012; Abourashed and El-Alfy, 2016; Kuete, 2017). While presently, review on NEO is still limited about its toxicological aspect (Ehrenpreis et al., 2014). Therefore, this article will highlight the scientific reports of NEO chemical composition, bioactivities, and toxicity, with special attention to bioactive compounds and the mechanism underlying their effect.

\section{MATERIALS AND METHODS}

This review utilizes narrative review in favor of its perceived strength in identifying accomplishments and gaps of previous studies (Rother, 2007; Grant and Booth, 2009). A web-based purposive literature search was conducted by using 'Myristica fragrance in combination with: 'nutmeg', 'essential oil', 'chemical composition', 'bioactivity', and 'toxicity' as the keywords. The searching process was limited to the recently published literature from 2000 to 2020.

\section{RESULT AND DISCUSSION}

This review summarized pharmacological studies on NEO over the last 20 years (2000-2020). This review particularly focused on NEO chemical composition, biological activities, and toxicity to compile NEO wholesome profile for the sake of NEO development into medicinal products with diverse pharmacological properties.

\section{Chemical composition}

NEO is rich in monoterpenes (about 90\%) and phenylpropanoids (Abourashed and El-Alfy, 2016). Several reports on GC/MS analysis of NEO showed that there were 27-38 compounds detected at various concentrations (Abourashed and El-Alfy, 2016). Kapoor et al. (2013) identified 38 compounds in NEO. While two individual studies conducted by Wahab et al. (2009) and Piaru et al. (2012) successfully identified 37 chemical compounds in the NEO. While in other studies, Muchtaridi, et al. (2010) recorded 32 constituents, Piras et al. (2012) reported 30 compounds, and Du et al. (2014) identified 27 compounds. Thus, the average number of chemical constituents in NEO detected based on these studies is 34 .

The monoterpenes that are commonly identified in NEO are $\alpha$-pinene (1), $\beta$-pinene (2), 4terpineol (3), $\alpha$-terpinene (4), $\gamma$-terpinene (5), limonene (6), sabinene (7), $\alpha$-terpineol (8), camphene (9), and myrcene (10). Whereas the phenylpropanoids compounds that can be found are myristicin (11), elemicin (12), safrole (13), eugenol (14), methyl eugenol (15), and methyl isoeugenol (16) (Figue 1).

\section{Biological activities}

NEO has various pharmacological properties and active constituents, such as $\alpha$-pinene, elemicin, 4-terpineol, myristicin, eugenol, safrole, and linalool (Table I). 
Table Ia. Myristica fragrans Houtt. essential oil bioactivities

\begin{tabular}{|c|c|c|c|}
\hline $\begin{array}{cc}\text { Biological } & \text { Study } \\
\text { activities } & \text { model } \\
\end{array}$ & Assay & $\begin{array}{c}\text { Concentration or } \\
\text { dose }\end{array}$ & $\begin{array}{l}\text { Active constituent of } \\
\text { NEO }\end{array}$ \\
\hline Antioxidant In vitro & $\begin{array}{l}\text { Radioprotection } \\
\text { OH. Assay } \\
\beta \text {-carotene bleaching } \\
\text { Reducing power }\left(\mathrm{EC}_{50}\right)\end{array}$ & $\begin{array}{l}2.94 \pm 0.09 \mu \mathrm{M} \mathrm{g}^{-1} \\
\text { TEAC } \\
100 \mu \mathrm{M} \mathrm{g}^{-1} \mathrm{TEAC}^{-1} \\
308.8 \pm 14.08 \mu \mathrm{M} \mathrm{g}^{-1} \\
\text { BHT eq. } \\
25.11 \pm 1.50 \mu \mathrm{M} \mathrm{g}^{-1} \\
\text { BHT eq. } \\
181.4 \mu \mathrm{gL}^{-1}\end{array}$ & $\begin{array}{l}\text { Elemicin, 4-terpineol, (Gupta and Rajpurohit, } \\
\text { myristicin, trans-2011; Piaru et al., } \\
\text { sabinene hydrate,2012b; Adiani et al., } \\
\text { safrole, eugenol, } \quad \beta-2015) \\
\text { caryophyllene, } \\
\text { isoeugenol, sabinene, } \alpha \text { - } \\
\text { pinene, limonene, and } \\
\alpha \text {-terpinene }\end{array}$ \\
\hline $\begin{array}{l}\text { Analgesic and In vivo } \\
\text { anti- } \\
\text { inflammation }\end{array}$ & $\begin{array}{l}\text { Rats induced CFA- } \\
\text { injection }\end{array}$ & $20 \mathrm{mg} \mathrm{kg}^{-1}$ & $\begin{array}{ll}\gamma \text {-Terpinene, linalool, (Wahab et al., 2009; } & \text { 2012; } \\
\text { myristicin, safrole, Asgarpanah, } & \text { de Cássia da Silveira e } \\
\text { eugenol, and elemicin } & \text { Sá et al., 2014; Passos et } \\
& \text { al., 2015) }\end{array}$ \\
\hline $\begin{array}{l}\text { Anti- } \\
\text { convulsant }\end{array}$ & $\begin{array}{l}\text { Electroshock seizure } \\
\text { test in mice }\end{array}$ & $200 \mu \mathrm{L} \mathrm{kg}^{-1}$ & $\begin{array}{l}\text { Pinene analog, linalool, (Wahab et al., 2009; } \\
\begin{array}{l}\alpha \text {-terpineol, eugenol, de Sousa et al., } \\
\text { and citronellol }\end{array} \quad \text { Bahr et al., 2019) }\end{array}$ \\
\hline fection In vitro & $\begin{array}{l}\text { Anti-parasitic assay } \\
\text { (EC50) } \\
\text { Toxoplasma gondii } \\
\text { Intracellular anti- } \\
\text { amastigote test (IC50) } \\
\text { Leishmania amazonensis } \\
\text { Dilution method (MIC) } \\
\text { S. aureus } \\
\text { E. coli } \\
\text { P. vulgaris } \\
\text { B. subtilis } \\
\text { K. pneumoniae } \\
\text { B. megaterium } \\
\text { Disk diffution method } \\
\text { P. aeruginosa } \\
\text { S. epidermis } \\
\text { S. dysenteriae, } \\
\text { S. typhi }\end{array}$ & $\begin{array}{l}133.5 \mu \mathrm{g} \mathrm{mL}-1 \\
8 \mu \mathrm{L} \text { at } 12.5 \% \mathrm{v} / \mathrm{v} \\
12 \mu \mathrm{L} \text { at } 12.5 \% \mathrm{v} / \mathrm{v} \\
10 \mu \mathrm{L} \text { at } 12.5 \% \mathrm{v} / \mathrm{v} \\
10 \mu \mathrm{L} \text { at } 12.5 \% \mathrm{v} / \mathrm{v} \\
8 \mu \mathrm{L} \text { at } 12.5 \% \mathrm{v} / \mathrm{v} \\
14 \mu \mathrm{L} \text { at } 12.5 \% \mathrm{v} / \mathrm{v}\end{array}$ & $\begin{array}{l}\text { Linalool, } \\
\text { caryophyllene, pinene 2004; Prabuseenivasan } \\
\text { analogs, p-cymene, and et al., 2006; Gupta and } \\
\text { carvacrol } \\
\text { Rajpurohit, 2011; Pillai } \\
\text { et al., 2012; Soni et al., } \\
\text { 2016; Nurjanah et al., } \\
\text { 2017; Monzote et al, } \\
\text { 2019) }\end{array}$ \\
\hline
\end{tabular}

\section{Antioxidant}

The production of reactive oxygen and nitrogen species (ROS/RNS) causes oxidative stress that prompts the development of age-related ailments such as neurodegenerative diseases, kidney disorder, cardiovascular maladies, macular degeneration, biliary diseases, cancer, and chronic obstructive pulmonary disease, as well as sarcopenia and frailty (Huang et al., 2005; Liguori et al., 2018). Antioxidants are compounds that prevent the oxidation process or neutralize free radicals i.e., (ROS/RNS) (Oke et al., 2009; Yashin et al., 2017); therefore, they are potentially used to treat age-related and disease-related oxidative stress (Liguori et al., 2018). Spices and aromatic herbs are rich sources of chemical compounds with antioxidant properties (Yashin et al., 2017), including nutmeg (Dragland et al., 2003).

It was reported that the drying method of nutmeg fruit flesh influenced the NEO quality. The shade-drying method had the best antioxidant activity (72.82\%) in comparison with the fresh or without drying (24.18\%) and sun-drying (45.56\%) methods (Sipahelut et al., 2020). Antioxidant activity test with various methods on NEO reported that NEO had antioxidant value with Trolox equivalents of $2.94 \pm 0.09 \mu \mathrm{Mg}^{-1}$ [2,2-diphenyl-1picrylhydrazyl (DPPH) assay], $100 \mu \mathrm{Mg}^{-1}$ (radioprotective potential), and 308.8 \pm 14.08 $\mu \mathrm{Mg}^{-1}$ (OH. assay), as well as $25.11 \pm 1.50 \mu \mathrm{Mg}^{-1} \mathrm{BHT}$ equivalent ( $\beta$-carotene/linoleic acid assay) (Adiani et al., 2015). Another study reported that NEO had reducing power with an $\mathrm{EC}_{50}$ value of $181.4 \mu \mathrm{g} \mathrm{mL}^{-1}$ (Piaru et al., 2012b). 
Table Ib. Myristica fragrans Houtt. essential oil bioactivities

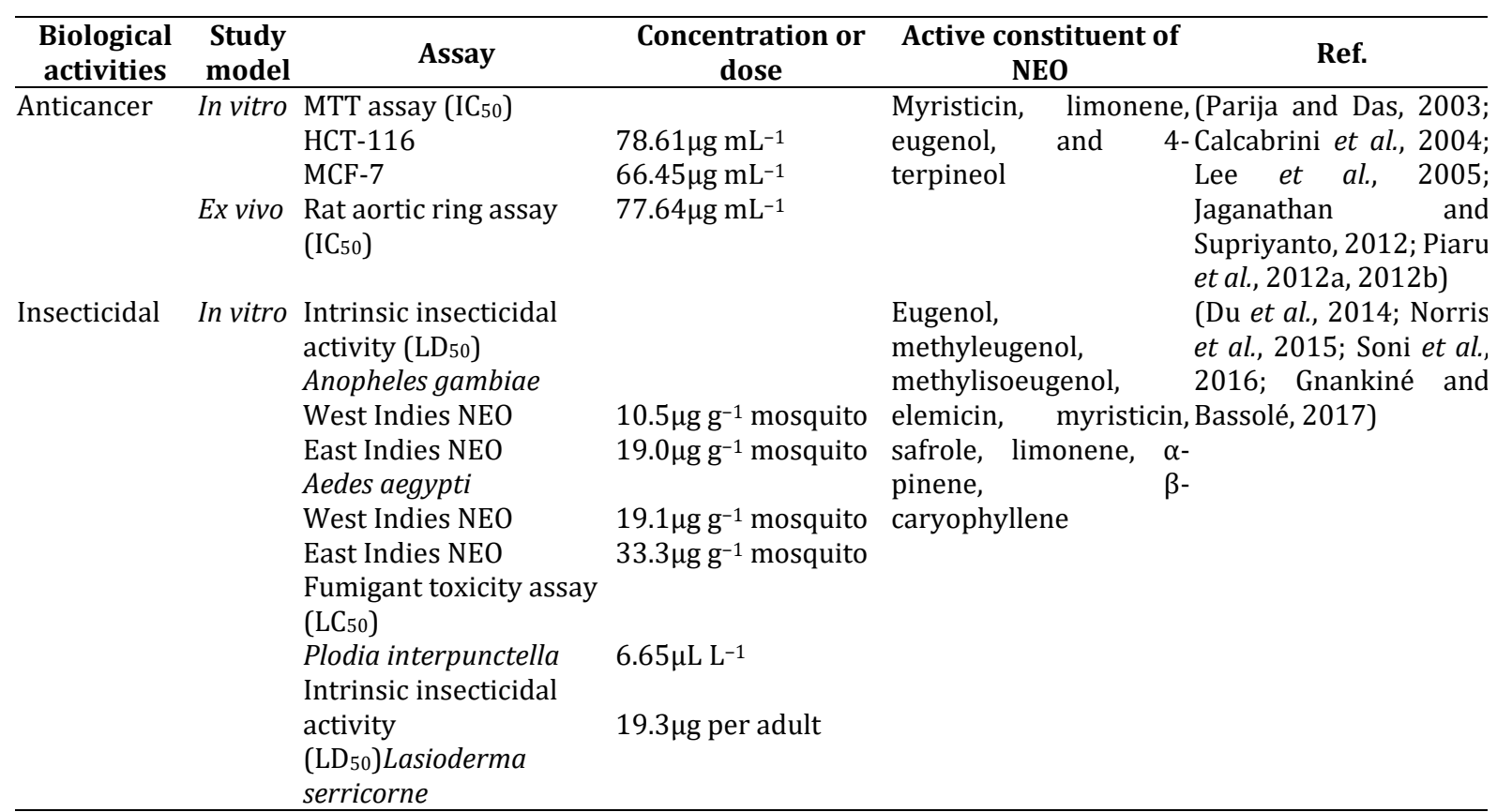

Reports on NEO's antioxidant constituents were found in various studies. The antioxidant constituents are including elemicin, 4-terpineol, myristicin, trans-sabinene hydrate (Adiani et al., 2015), safrole, eugenol, $\beta$-caryophyllene, and isoeugenol (Gupta and Rajpurohit, 2011). Elemicin was reported to be the most potent antioxidant compound (Adiani et al., 2015). Eugenol and $\beta$ caryophyllene have hydrogen atoms in the benzylic and/or allylic positions that could easily interact with peroxyl radicals formed under oxidative stress. Eugenol also stimulates the activities of various enzymes that might be beneficial contributors for antioxidant activity e.g., glutamine transferase, catalase, glutathione peroxidase, superoxide dismutase, and glucose-6-phosphate dehydrogenase enzymes (Gupta and Rajpurohit, 2011).

Analgesic and antiinflammation

Inflammation is a protective measure of the body to remove noxious stimuli, such as infection and tissue injury (Ferrero-Miliani et al., 2006), and to commence the recovery process (de Cássia da Silveira e Sá et al., 2014). Inflammation can be categorized into acute or chronic, depending on whether the duration of the symptom persists, whether short or a prolonged response (de Cássia da Silveira e Sá et al., 2014; Hawiger and
Zienkiewicz, 2019). Chronic inflammation is correlated with several chronic human ailments, such as allergy, atherosclerosis, cancer, arthritis, and autoimmune diseases (Medzhitov, 2008). NEO is traditionally used to relieve sprains, rheumatism, paralysis, and as an alternative remedy to ease toothache (Asgarpanah, 2012; Zhang et al., 2016).

NEO was a potential chronic pain reliever since it was reported to be able to alleviate mechanical allodynia, joint swelling, and heat hyper analgesia of rats stimulated by the complete Freund's adjuvant (CFA)-injection. Oral intake of $20 \mathrm{mg} \mathrm{kg}^{-1}$ NEO preparation decreases swelling, and pain scores significantly in comparison with the $30 \mathrm{mg} \mathrm{kg}^{-1}$ diclofenac treated group. The analgesic and antiinflammation activity of NEO was associated with its capability to inhibit the expression of blood substance P level and COX-2 (Zhang et al., 2016).

Several compounds that are responsible for the analgesic and antiinflammation activity of NEO are $\gamma$-terpinene, linalool (De Brito Passos et al., 2015), myristicin (Asgarpanah, 2012), safrole, eugenol, and elemicin (de Cássia da Silveira e Sá et al., 2014). At low doses, $\gamma$-Terpinene could exert an antinociceptive effect in capsaicin, formalin, and glutamate tests through the opioid system involvement via $\mathrm{K}^{+}{ }_{\text {ATP }}$ channels and the cholinergic 
system. $\gamma$-Terpinene could inhibit proinflammatory mediators and affect the neurotransmission pathways at the SNc level (such as substance P or CGRP)]. Safrole has a very weak anti-inflammatory activity with a percentage activity of rat paw edema inhibition of $5 \%$ at $50 \mathrm{mg}$ $\mathrm{kg}^{-1}$ body (Parise-Filho et al., 2011). Eugenol was reported to be able to suppress the production of thromboxane B2, prostaglandin, and leukotriene. In vivo experiments revealed that rats which were pretreated with eugenol at 25,50 , and $100 \mathrm{mg} \mathrm{kg}^{-1}$ doses were observed to be able to reduce the carrageenan-induced paw edema significantly by $28 \%, 62 \%$, and $78 \%$, respectively (de Cássia da Silveira e Sá et al., 2014). Myristicin antiinflammation activity was correlated with its aptitude to suppress the production of several inflammatory regulators, such as calcium, NO, IL-6, IL-10, macrophage inflammatory protein (MIP)-1 $\alpha$, MIP-1 $\beta$, granulocyte-macrophage colonystimulating factor (GM-CSF), interferon-inducible protein-10, monocyte, chemotactic protein (MCP)-1, MCP-3, and leukemia inhibitory factor (LIF, a member of IL-6 family) (Narasimhan and Dhake, 2006; Serhan, Chiang and Van Dyke, 2008; Lee and Park, 2011). While elemicin inhibited 5LOX, was reported as potent proinflammatory leukotrienes against rat basophil leukemia cells (RBL-1 cells) (de Cássia da Silveira e Sá et al., 2014). Other compounds that have been reported to have antiinflammation and analgesic activity are sabinene, $\alpha$-pinene, 4-terpineol, limonene, $\alpha$ terpinene) (Andrade et al., 2015; De Brito Passos et al., 2015; Khalilzadeh et al., 2015). $\alpha$-Pinene reported impeding the production of proinflammatory cytokines i.e., IL-1 $\beta$, TNF- $\alpha$, and IL- 6 , in rats prompted for acute pancreatitis (Bae et al., 2012).

\section{Anticonvulsant}

Convulsions happen because of the imbalance between excitatory and inhibitory neurotransmitters. NEO was reported to possess anticonvulsant activity in multiple seizure models. In the maximal electroshock seizure test, $200 \mu \mathrm{L} / \mathrm{kg}$ NEO was able to give total protection against hind limb tonic extension phase, while it gave doserelated effect in the pentylenetetrazol, bicuculline, and strychnine seizure tests. NEO's anticonvulsant activity was reported to have a rapid onset of action with a short duration of action (Wahab et al., 2009).

Compounds in the NEO that were reported to have an anticonvulsant effect are pinene analog, linalool, $\alpha$-terpineol (de Sousa et al., 2010), eugenol, and citronellol (Bahr et al., 2019). The pinene analogs are potent acetylcholinesterase inhibitors, that also work as a modulator on GABA receptors and increase the postsynaptic GABAdependent chloride flow (Zamyad et al., 2019). They also reduced the hippocampal nitrite level and striatal content of norepinephrine and dopamine (Felipe et al., 2019). Linalool affects glutamatergic transmission, it significantly reduces potassium-stimulated glutamate release and uptake, but does not obstruct basal glutamate release (Wahab et al., 2009). Eugenol blocks sodium current, which contributes to the modulation of neuronal hyperexcitability (Huang et al., 2012). Yet, the eugenol effect is dosedependent. Eugenol could have both neuronal repressive and excitant effects. At low concentration $(0.5 \mathrm{mM})$, it has an antiepileptic effect, while at higher concentration (2mM), it induces epileptiform activity (Vatanparast et al., 2017). Terpineol had a dose-dependent and reversible anticonvulsant effect. It inhibits the action potential propagation effect of the rat's sciatic nerve (Moreira et al., 2001).

Antiinfection

NEO was reported to have antibacterial, antifungal, and antiparasitic activities (Gupta and Rajpurohit, 2011; Pillai et al., 2012). The in vitro antiparasitic test of NEO against Toxoplasma gondii showed a promising inhibition activity with $\mathrm{EC}_{50}$ of $24.45 \mu \mathrm{g} \mathrm{mL}^{-1}$, which was comparable to inhibition properties of clinically standard drug, clindamycin, which had $\mathrm{EC}_{50}$ of $16.57 \mu \mathrm{g} \mathrm{mL}^{-1}$ (Pillai et al., 2012). It also had relatively weak antileishmanial activity against Leishmania amazonensis with an $\mathrm{IC}_{50}$ of $133.5 \mu \mathrm{g} \mathrm{mL} \mathrm{m}^{-1}$. Compounds that reportedly had antiparasitic activity were $\alpha$-pinene, linalool, and $\beta$ caryophyllene (Monzote et al., 2019).

NEO showed inhibition activity against Staphylococcus aureus, Proteus vulgaris, Klebsiella pneumoniae, Escherichia coli, Bacillus subtilis, Bacillus megaterium (Soni et al., 2016), Pseudomonas aeruginosa (Prabuseenivasan et al., 2006), Staphylococcus epidermis, Shigella dysenteriae, and Salmonella typhi (Nurjanah et al., 2017). Several compounds were identified to be responsible for the antimicrobial activity, i.e. pinene analogs, p-cymene, carvacrol, and $\beta$ caryophyllene (Dorman and Deans, 2004; Gupta and Rajpurohit, 2011). $\alpha$ - and $\beta$-pinene showed toxicity against membrane cells (Alma et al., 2004). $\alpha$-pinene was also found to be an antibiotic resistance modulator for $C$. jejuni that targets antimicrobial efflux systems (Kovač et al., 2015). Anticancer 
NEO also reported had cytotoxic effects against human colorectal carcinoma (HCT-116) and human breast carcinoma (MCF-7) cell lines with $\mathrm{IC}_{50}$ values of 78.61 and $66.45 \mu \mathrm{g} \mathrm{mL} \mathrm{L}^{-1}$, respectively (Piaru et al., 2012a). Additionally, the antiangiogenic activity of NEO was investigated $e x$ vivo using rat aortic ring assay and the $\mathrm{IC}_{50}$ was reported to be $77.64 \mu \mathrm{g} \mathrm{mL} \mathrm{m}^{-1}$ (Piaru et al., 2012b). Studies reported that several NEO compounds, i.e., myristicin, limonene, eugenol, and 4-terpineol, had an anti-cancer effect. Myristicin induces the activation of specific intracellular death-related pathways, which precedes caspase- 3 stimulation and apoptosis cytotoxicity initiation in human neuroblastoma SK-N-SH cells through apoptotic mechanism (Lee et al., 2005). D-limonene was reported to be a potential chemoprevention agent in $\mathrm{N}$-nitrosodiethylamine induced hepatocarcinoma in AKR mice models through its ability to inhibit the overexpression of c-myc oncoprotein (Parija and Ranjan Das, 2003). 4Terpineol was reported to be able to prompt caspase-dependent apoptosis of human melanoma M14 WT cells and M14 adriamycin-resistant cells (Calcabrini et al., 2004). Eugenol was reported to be able to stimulate apoptosis in osteosarcoma, skin tumors, melanoma, leukemia, gastric and mast cells (Jaganathan and Supriyanto, 2012).

Insecticidal

Essential oils are generally recognized as safe (GRAS) for the environment and human health. Therefore, NEO is a promising, eco-friendly, and safe insect repellent or insecticidal agent. A study in West Indies and East Indies highlighted NEO toxicity against adult female Anopheles gambiae at $\mathrm{LD}_{50}$ of 10.5 and $19.0 \mathrm{\mu g} \mathrm{g}^{-1}$ mosquito, respectively, while they had $\mathrm{LD}_{50}$ of 19.1 and $33.3 \mu \mathrm{g} \mathrm{g}^{-1}$ mosquito against adult female Aedes aegypti (Norris et al., 2015). Another study reported that NEO had $\mathrm{LC}_{50}$ of $6.65 \mu \mathrm{L} \mathrm{L}^{-1}$ air against Plodia interpunctella adults (Soni et al., 2016) and $\mathrm{LD}_{50}$ of $19.3 \mu \mathrm{g} /$ adult Lasioderma serricorne (Du et al., 2014). Six active compounds i.e., eugenol, methyleugenol, methylisoeugenol, elemicin, myristicin, and safrole, were identified in the study (Du et al., 2014).

NEO compounds, i.e. limonene, eugenol, $\alpha$ pinene, $\beta$-caryophyllene (Gnankiné and Bassolé, 2017), and myristicin (Srivastava et al., 2001) were reported to be responsible for the insecticidal activity. Myristicin was also reported to have $\mathrm{LD}_{50}$ of $104 \mathrm{mg}$ per larva against Spilarctia obliqua and $\mathrm{LD}_{100}$ of 25 ppm against Aedes aegypti (Srivastava et al., 2001).

\section{Toxicity}

Large intake of NEO might result in intoxication with symptoms such as facial flushing, blurred vision, dry mouth, hypertension, tachycardia, nausea, vomiting, feelings of euphoria and unreality, delirium, agitation, abdominal pain, or hallucinations (Stein et al., 2001; Gupta and Rajpurohit, 2011; Ehrenpreis et al., 2014). The LD50 of NEO is $2150 \mu \mathrm{L} \mathrm{kg}^{-1}$ (Wahab et al., 2009). NEO toxic effects are attributed to myristicin, safrole, elemicin, 4-terpineol (Stein et al., 2001; Beyer et al., 2006; Muchtaridi et al., 2010).

Elemicin and myristicin were assumed to cause NEO psychoactivity through a metabolic process in the body and converted into amphetamine derivatives (Gupta and Rajpurohit, 2011; Ehrenpreis et al., 2014). Elemicin is metabolized to 3,4,5-trimethoxyamphetamine, while myristicin to 3-methoxy-4 5-methylenedioxy amphetamine (Stein et al., 2001). Myristicin is also a weak monoamine oxidase inhibitor, that is accountable for certain cardiovascular symptoms (Gupta and Rajpurohit, 2011). Myristicin, 4terpineol, and safrole were also reported to be associated with locomotor activity inhibition in mice (Muchtaridi et al., 2010). Low concentrations of GABA, 4-terpineol, and $\alpha$-terpineol were reportedly able to potentiate the $\mathrm{GABA}_{\mathrm{A}}$ receptormediated response such as sedative and anxiolytic effects (Aoshima et al., 2001; Hossain et al., 2002).

\section{CONCLUSION}

NEO can be obtained from seed, leaf, or mace of $M$. fragrans. It is rich in terpenes and phenylpropanoids. The analysis of NEO was mostly done using GC, especially GC/MS methods. The main bioactive substances of NEO are pinene derivates, elemicin, 4-terpineol, myristicin, eugenol, and linalool.

NEO has various pharmacological functions including antioxidant, analgesic, antiinflammation, anticonvulsant, antibacterial, antiparasitic, anticancer/chemopreventive, and insecticidal activities. Further studies particularly in vitro studies and biological activity tests directing to in vivo pharmacokinetic and pharmacodynamic evaluation that lead to the development of new drug entities are still needed to explore NEO's potential as new therapeutic drugs.

\section{ACKNOWLEDGEMENT}

Sincere gratitude is extended to the Ministry of Research and Technology / National Research and Innovation Agency for the research grant 
(Riset Inovatif Produktif/RISPRO scheme No. 164/E1/PRN/2020 entitled Development of essential oil standardization method through the determination of antiaging and antioxidant active compounds utilizing chemometric analysis).

\section{REFERENCES}

Abourashed E.A., El-Alfy A.T., 2016. Chemical diversity and pharmacological significance of the secondary metabolites of nutmeg (Myristica fragrans Houtt.). Phytochem Rev, 15 (6): 1035-1056, doi: 10.1007/s11101016-9469-x

Adiani V., Gupta S., Chatterjee S., Variyar P.S., Sharma A., 2015. Activity guided characterization of antioxidant components from essential oil of Nutmeg (Myristica fragrans). Journal of Food Science and Technology, 52 (1): 221-230, doi: 10.1007/s13197-013-1034-7

Alma M.H., Nitz S., Kollmannsberger H., Digrak M., Efe F.T., Yilmaz N., 2004. Chemical Composition and Antimicrobial Activity of the Essential Oils from the Gum of Turkish Pistachio ( Pistacia vera L . ). J. Agric. Food Chem., 52 (12): 3911-3914, doi: 10.1021/jf040014e

Al-Rawi S.S., Ibrahim A.H., Rahman N.N.N.A., Nama M.M.B., Majid A.M.S.A., Kadir M.O.A., 2011. The Effect of Supercritical Fluid Extraction Parameters on the Nutmeg Oil Extraction and Its Cytotoxic and Antiangiogenic Properties. Procedia Food Science, 11946-1952, doi: 10.1016/j.profoo.2011.09.286

Andrade M.A., Cardoso M.D.G., Gomes M. de S., de Azeredo C.M.O., Batista L.R., Soares M.J., Rodrigues L.M.A., Figueiredo A.C.S., 2015. Biological activity of the essential oils from Cinnamodendron dinisii and Siparuna guianensis. Brazilian Journal of Microbiology, 46 (1): 189-194, doi: 10.1590/S1517838246120130683

Aoshima H., Julfikar Hossain S., Hamamoto K., Yokoyama T., Yamada M., Shingai R., 2001. Kinetic Analyses of Alcohol-Induced Potentiation of the Response of GABAA Receptors Composed of 1 and 1 Subunits. Journal of Biochemistry, 130 (5): 703-709, doi:

10.1093/oxfordjournals.jbchem.a003037

Asgarpanah J., 2012. Phytochemistry and pharmacologic properties of Myristica fragrans Hoyutt.: A review. Afr. J. Biotechnol.,
11 (65): 12787-12793, doi: 10.5897/AJB12.1043

Bae G.-S., Park K.-C., Choi S.B., Jo I.-J., Choi M.-O., Hong S.-H., Song K., Song H.-J., Park S.-J., 2012. Protective effects of alpha-pinene in mice with cerulein-induced acute pancreatitis. Life Sciences, 91 (17-18): 866-871, doi: 10.1016/j.lfs.2012.08.035

Bahr T.A., Rodriguez D., Beaumont C., Allred K., 2019. The Effects of Various Essential Oils on Epilepsy and Acute Seizure: A Systematic Review. Evidence-Based Complementary and Alternative Medicine, 20191-14, doi: 10.1155/2019/6216745

Beyer J., Ehlers D., Maurer H.H., 2006. Abuse of Nutmeg (Myristica fragrans Houtt.): Studies on the Metabolism and the Toxicologic Detection of its Ingredients Elemicin, Myristicin, and Safrole in Rat and Human Urine Using Gas Chromatography/Mass Spectrometry: Therapeutic Drug Monitoring, 28 (4): 568-575, doi: 10.1097/00007691200608000-00013

Calcabrini A., Stringaro A., Toccacieli L., Meschini S., Marra M., Colone M., Arancia G., Molinari A., Salvatore G., Mondello F., 2004. Terpinen-4ol, The Main Component of Melaleuca Alternifolia (Tea Tree) Oil Inhibits the In Vitro Growth of Human Melanoma Cells. Journal of Investigative Dermatology, 122 (2): 349-360, doi: 10.1046/j.0022202X.2004.22236.x

De Brito Passos F.F., Lopes E.M., De Araújo J.M., De Sousa D.P., Veras L.M.C., Leite J.R.S.A., De Castro Almeida F.R., 2015. Involvement of Cholinergic and Opioid System in $\gamma$ Terpinene-Mediated Antinociception. Evidence-based Complementary and Alternative Medicine, 2015, doi: 10.1155/2015/829414

de Cássia da Silveira e Sá R., Andrade L., dos Reis Barreto de Oliveira R., de Sousa D., 2014. A Review on Anti-Inflammatory Activity of Phenylpropanoids Found in Essential Oils. Molecules, 19 (2): 1459-1480, doi: 10.3390/molecules19021459

de Sousa D.P., Nóbrega F.F.F., Santos C.C.M.P., de Almeida R.N., 2010. Anticonvulsant Activity of the Linalool Enantiomers and Racemate: Investigation of Chiral Influence. Natural Product Communications, 5 (12): 1934578X1000501, doi: $10.1177 / 1934578 X 1000501201$ 
Dorman H.J.D., Deans S.G., 2004. Chemical Composition, Antimicrobial and In Vitro Antioxidant Properties of Monarda citriodora var. citriodora, Myristica fragrans, Origanum vulgare ssp. hirtum, Pelargonium sp. and Thymus zygis Oils. Journal of Essential Oil Research, 16 (2): 145-150, doi: $10.1080 / 10412905.2004 .9698679$

Dragland S., Senoo H., Wake K., Holte K., Blomhoff R., 2003. Several Culinary and Medicinal Herbs Are Important Sources of Dietary Antioxidants. The Journal of Nutrition, 133 (5): 1286-1290, doi: 10.1093/jn/133.5.1286

Du S.-S., Yang K., Wang C.-F., You C.-X., Geng Z.-F., Guo S.-S., Deng Z.-W., Liu Z.-L., 2014. Chemical Constituents and Activities of the Essential Oil from Myristica fragrans against Cigarette Beetle Lasioderma serricorne. Chemistry \& Biodiversity, 11 (9): 1449-1456, doi: 10.1002/cbdv.201400137

Ehrenpreis J.E., DesLauriers C., Lank P., Armstrong P.K., Leikin J.B., 2014. Nutmeg Poisonings: A Retrospective Review of 10 Years Experience from the Illinois Poison Center, 2001-2011. J. Med. Toxicol., 10 (2): 148-151, doi: 10.1007/s13181-013-0379-7

Felipe C.F.B., Albuquerque A.M.S., de Pontes J.L.X., de Melo J.Í.V., Rodrigues T.C.M.L., de Sousa A.M.P., Monteiro Á.B., Ribeiro A.E. da S., Lopes J.P., de Menezes I.R.A., de Almeida R.N., 2019. Comparative study of alpha- and beta-pinene effect on PTZ-induced convulsions in mice. Fundam Clin Pharmacol, 33 (2): 181-190, doi: 10.1111/fcp.12416

Ferrero-Miliani L., Nielsen O.H., Andersen P.S., Girardin S.E., 2006. Chronic inflammation: importance of NOD2 and NALP3 in interleukin-1? generation. Clin Exp Immunol, o (0): 061127015327006-???, doi: 10.1111/j.1365-2249.2006.03261.x

Gnankiné O., Bassolé I.L.H.N., 2017. Essential oils as an alternative to pyrethroids' resistance against anopheles species complex giles (Diptera: Culicidae). Molecules, 22 (10): , doi: $10.3390 /$ molecules 22101321

Grant M.J., Booth A., 2009. A typology of reviews : an analysis of 14 review types and. Health Information and Libraries Journal, 2691-108, doi: 10.1111/j.1471-1842.2009.00848.x

Gupta A.D., Rajpurohit D., 2011. Antioxidant and Antimicrobial Activity of Nutmeg (Myristica fragrans). In: Nuts and Seeds in Health and Disease Prevention. ELSEVIER, 831-839
Hawiger J., Zienkiewicz J., 2019. Decoding inflammation, its causes, genomic responses, and emerging countermeasures. Scand J Immunol, 90 (6): , doi: $10.1111 /$ sji.12812

Hossain S.J., Hamamoto K., Aoshima H., Hara Y., 2002. Effects of Tea Components on the Response of GABA ${ }_{\mathrm{A}}$ Receptors Expressed in Xenopus Oocytes. J. Agric. Food Chem., 50 (14): 3954-3960, doi: 10.1021/jf011607h

Huang C.-W., Chow J.C., Tsai J.-J., Wu S.-N., 2012. Characterizing the effects of Eugenol on neuronal ionic currents and hyperexcitability. Psychopharmacology, 221 (4): 575-587, doi: 10.1007/s00213-0112603-y

Huang D., Ou B., Prior R.L., 2005. The Chemistry behind Antioxidant Capacity Assays. J. Agric. Food Chem., 53 (6): 1841-1856, doi: 10.1021/jf030723c

Ibrahim M.A., Cantrell C.L., Jeliazkova E.A., Astatkie T., Zheljazkov V.D., 2020. Utilization of Nutmeg (Myristica fragrans Houtt.) Seed Hydrodistillation Time to Produce Essential Oil Fractions with Varied Compositions and Pharmacological Effects10

$\begin{array}{llll}\text { Jaganathan } & \text { S.K., } & \text { Supriyanto } & \text { E., } \\ & 2012 .\end{array}$ Antiproliferative and Molecular Mechanism of Eugenol-Induced Apoptosis in Cancer Cells. Molecules, 17 (6): 6290-6304, doi: 10.3390/molecules17066290

Jinous Asgarpanah, 2012. Phytochemistry and pharmacologic properties of Myristica fragrans Hoyutt.: A review. Afr. J. Biotechnol., 11 (65): , doi: 10.5897/AJB12.1043

Khalilzadeh E., Vafaei Saiah G., Hasannejad H., Ghaderi A., Ghaderi S., Hamidian G., Mahmoudi R., Eshgi D., Zangisheh M., 2015. Antinociceptive effects, acute toxicity and chemical composition of Vitex agnus-castus essential oil. Avicenna Journal of Phytomedicine, 5 (3): 218-30, doi: 10.22038/ajp.2015.4048

Kovač J., Šimunović K., Wu Z., Klančnik A., Bucar F., Zhang Q., Možina S.S., 2015. Antibiotic Resistance Modulation and Modes of Action of $(-)-\alpha$-Pinene in Campylobacter jejuni. PLOS ONE, 10 (4): e0122871, doi: 10.1371/journal.pone.0122871

Kuete V., 2017. Myristica fragrans: A Review. In: Medicinal Spices and Vegetables from Africa. ELSEVIER, 497-512

Lee B.K., Kim J.H., Jung J.W., Choi J.W., Han E.S., Lee S.H., Ko K.H., Ryu J.H., 2005. Myristicin- 
induced neurotoxicity in human neuroblastoma SK-N-SH cells. Toxicology Letters, 157 (1): 49-56, doi: 10.1016/j.toxlet.2005.01.012

Lee J.Y., Park W., 2011. Anti-Inflammatory Effect of Myristicin on RAW 264.7 Macrophages Stimulated with Polyinosinic-Polycytidylic Acid. Molecules, 16 (8): 7132-7142, doi: 10.3390/molecules16087132

Liguori I., Russo G., Curcio F., Bulli G., Aran L., DellaMorte D., Gargiulo G., Testa G., Cacciatore F., Bonaduce D., Abete P., 2018. Oxidative stress, aging, and diseases. CIA, Volume 13757-772, doi: 10.2147/CIA.S158513

Medzhitov R., 2008. Origin and physiological roles of inflammation. Nature, 454 (7203): 428-435, doi: 10.1038/nature07201

Monzote L., Herrera I., Satyal P., Setzer W., 2019. InVitro Evaluation of 52 CommerciallyAvailable Essential Oils Against Leishmania amazonensis. Molecules, 24 (7): 1248, doi: 10.3390/molecules24071248

Moreira M.R., Cruz G.M.P., Lopes M.S., Albuquerque A.A.C., Leal-Cardoso J.H., 2001. Effects of terpineol on the compound action potential of the rat sciatic nerve. Braz J Med Biol Res, 34 (10): 1337-1340, doi: 10.1590/S0100879X2001001000015

Muchtaridi, Subarnas A., Apriyantono A., Mustarichie R., 2010. Identification of Compounds in the Essential Oil of Nutmeg Seeds (Myristica fragrans Houtt.) That Inhibit Locomotor Activity in Mice. IJMS, 11 (11): 4771-4781, doi: 10.3390/ijms11114771

Narasimhan B., Dhake A.S., 2006. Antibacterial Principles from Myristica fragrans Seeds. Journal of Medicinal Food, 9 (3): 395-399, doi: 10.1089/jmf.2006.9.395

Norris E.J., Gross A.D., Dunphy B.M., Bessette S., Bartholomay L., Coats J.R., 2015. Comparison of the Insecticidal Characteristics of Commercially Available Plant Essential Oils Against Aedes aegypti and Anopheles gambiae (Diptera: Culicidae). J Med Entomol, 52 (5): 993-1002, doi: 10.1093/jme/tjv090

Nurjanah S., Putri I.L., Sugiarti D.P., 2017. Antibacterial Activity of Nutmeg Oil. KLS, 2 (6): 563, doi: 10.18502/kls.v2i6.1076

Oke F., Aslim B., Ozturk S., Altundag S., 2009. Essential oil composition, antimicrobial and antioxidant activities of Satureja cuneifolia Ten. Food Chemistry, 112 (4): 874-879, doi: 10.1016/j.foodchem.2008.06.061
Parija T., Das B.R., 2003. Involvement of YY1 and its correlation with c-myc in NDEA induced hepatocarcinogenesis, its prevention by $\mathrm{d}$ limonene. Molecular Biology Reports, 3041-46

Parija T., Ranjan Das B., 2003. [No title found]. Molecular Biology Reports, 30 (1): 41-46, doi: 10.1023/A:1022207630482

Parise-Filho R., Pastrello M., Pereira Camerlingo C.E., Silva G.J., Agostinho L.A., de Souza T., Motter Magri F.M., Ribeiro R.R., Brandt C.A., Polli M.C., 2011. The anti-inflammatory activity of dillapiole and some semisynthetic analogues. Pharmaceutical Biology, 49 (11): 1173-1179, doi: $10.3109 / 13880209.2011 .575793$

Passos F.F. de B., Lopes E.M., de Araújo J.M., de Sousa D.P., Veras L.M.C., Leite J.R.S.A., Almeida F.R. de C., 2015. Involvement of Cholinergic and Opioid System in $\gamma$ Terpinene-Mediated Antinociception. Evidence-Based Complementary and Alternative Medicine, 20151-9, doi: 10.1155/2015/829414

Periasamy G., Karim A., Gibrelibanos M., Gebremedhin G., Gilani A.-H., 2016. Nutmeg (Myristica fragrans Houtt.) Oils. In: Essential Oils in Food Preservation, Flavor and Safety. ELSEVIER, 607-616

Piaru S.P., Mahmud R., Abdul Majid A.M.S., Ismail S., Man C.N., 2012a. Chemical composition, antioxidant and cytotoxicity activities of the essential oils of Myristica fragrans and Morinda citrifolia. Journal of the Science of Food and Agriculture, 92 (3): 593-597, doi: $10.1002 /$ jsfa.4613

Piaru S.P., Mahmud R., Abdul Majid A.M.S., Mahmoud Nassar Z.D., 2012b. Antioxidant and antiangiogenic activities of the essential oils of Myristica fragrans and Morinda citrifolia. Asian Pacific Journal of Tropical Medicine, 5 (4): 294-298, doi: 10.1016/S1995-7645(12)60042-X

Pillai S., Mahmud R., Lee W.C., Perumal S., 2012. Anti-Parasitic Activity of Myristica Fragrans Houtt. Essential Oil Against Toxoplasma Gondii Parasite. APCBEE Procedia, 292-96, doi: 10.1016/j.apcbee.2012.06.017

Prabuseenivasan S., Jayakumar M., Ignacimuthu S., 2006. In vitro antibacterial activity of some plant essential oils. BMC Complement Altern Med, 6 (1): 39, doi: 10.1186/1472-6882-639 
Rahardiyan D., Poluakan M., Moko E.M., 2020. Physico-chemical Properties of Nutmeg (Myristica fragrans houtt) of North Sulawesi Nutmeg9

Rother E., 2007. Editorial: Systematic Review X Narrative Review. Acta Paulista de Enfermagem, 20 (2): 7-8, doi: 10.1590/S0103-21002007000200001

Serhan C.N., Chiang N., Van Dyke T.E., 2008. Resolving inflammation: dual antiinflammatory and pro-resolution lipid mediators. Nat Rev Immunol, 8 (5): 349-361, doi: $10.1038 / \mathrm{nri} 2294$

Sipahelut S.G., Kastanja A.Y., Patty Z., 2020. Antioxidant activity of nutmeg fruit fleshderived essential oil obtained through multiple drying methods. EurAsian Journal of BioSciences6

Soni R., Sharma G., Jasuja N.D., 2016. Essential Oil Yield Pattern and Antibacterial and Insecticidal Activities of Trachyspermum ammi and Myristica fragrans. Scientifica, 20161-7, doi: 10.1155/2016/1428194

Srivastava S., Gupta M.M., Prajapati V., Tripathi A.K., Kumar S., 2001. Insecticidal activity of myristicin from piper mullesua. Pharmaceutical Biology, 39 (3): 226-229, doi: 10.1076/phbi.39.3.226.5933

Stein U., Greyer H., Hentschel H., 2001. Nutmeg (myristicin) poisoning $Ð$ report on a fatal case and a series of cases recorded by a poison information centre. Forensic Science International4

Vatanparast J., Khalili S., Naseh M., 2017. Dual effects of eugenol on the neuronal excitability: An in vitro study. NeuroToxicology, 5884-91, doi: 10.1016/j.neuro.2016.11.011
Wahab A., Haq R.U., Ahmed A., Khan R.A., Raza M., 2009. Anticonvulsant activities of nutmeg oil of Myristica fragrans. Phytotherapy Research, 23 (2): 153-158, doi: 10.1002/ptr.2548

Yashin A., Yashin Y., Xia X., Nemzer B., 2017. Antioxidant Activity of Spices and Their Impact on Human Health: A Review. Antioxidants, 6 (3): 70, doi: 10.3390/antiox6030070

Zamyad M., Abbasnejad M., Esmaeili-Mahani S., Mostafavi A., Sheibani V., 2019. The anticonvulsant effects of Ducrosia anethifolia (Boiss) essential oil are produced by its main component alpha-pinene in rats. Arq. Neuro-Psiquiatr., 77 (2): 106-114, doi: 10.1590/0004-282x20180147

Zhang W.K., Tao S.-S., Li T.-T., Li Y.-S., Li X.-J., Tang H.-B., Cong R.-H., Ma F.-L., Wan C.-J., 2016. Nutmeg oil alleviates chronic inflammatory pain through inhibition of COX-2 expression and substance $\mathrm{P}$ release in vivo. Food \& Nutrition Research, 60: 30849, doi: 10.3402/fnr.v60.30849

Zhao L., Tian S., Wen E., Upur H., 2017. An ethnopharmacological study of aromatic Uyghur medicinal plants in Xinjiang, China. Pharmaceutical Biology, 55 (1): 1114-1130, doi: 10.1080/13880209.2016.1270971

Zheljazkov V.D., Gawde A., Cantrell C.L., Astatkie T., Schlegel V., 2015. Distillation Time as Tool for Improved Antimalarial Activity and Differential Oil Composition of Cumin Seed Oil. PLoS ONE, 10 (12): e0144120, doi: 10.1371/journal.pone.0144120 